Research Article

\title{
Research on Balanced Content of Magnesium Oxide in Roller Compacted Concrete
}

\author{
Changli Chen $(\mathbb{D}$, Rongfei Chen, Peng Zhao, and Dongsheng Yang \\ School of Materials and Architecture Engineering, Guizhou Normal University, Guiyang 550025, China \\ Correspondence should be addressed to Changli Chen; gzgyccl@tom.com
}

Received 25 June 2020; Accepted 14 August 2020; Published 25 August 2020

Academic Editor: Veronica Calado

Copyright (C) 2020 Changli Chen et al. This is an open access article distributed under the Creative Commons Attribution License, which permits unrestricted use, distribution, and reproduction in any medium, provided the original work is properly cited.

In order to accelerate the application of magnesium oxide $(\mathrm{MgO})$ expanding admixture in roller compacted concrete (RCC), aiming at common three-grading RCC used in water conservancy and hydropower engineering, the autoclave expansion of mortar specimens and the compressive strength of the autoclaved mortar specimens were studied by means of autoclave test and compressive strength test. Results showed that the balanced $\mathrm{MgO}$ content in RCC, which cannot be determined by the MgO content corresponding to $0.5 \%$ autoclave expansion rate of mortar specimens or the inflection point of the curve of autoclave expansion changing with $\mathrm{MgO}$ content like normal concrete, should be determined by the $\mathrm{MgO}$ content corresponding to the inflection point of the curve that compressive strength of autoclaved mortar specimens changes with $\mathrm{MgO}$ content to ensure longterm safe operation of RCC dams.

\section{Introduction}

A large number of experimental studies and engineering practices show that the magnesium oxide $(\mathrm{MgO})$ concrete, which is formed by mixing with $\mathrm{MgO}$ expansion agent in concrete, has excellent delayed microexpansion characteristics. This delayed microexpansion can compensate for the volume shrinkage of dam concrete during the long temperature drop. Thus, the desire of simplifying or even canceling the temperature control measures of dam concrete, speeding up the construction progress, and saving project investment can be realized [1-10]. Therefore, $\mathrm{MgO}$ concrete has been increasingly used in small and mediumsized water conservancy and hydropower engineering in China, up to now more than 50 , and its application has been extended from normal concrete dam to roller compacted concrete (RCC) dam [11-18]. However, in other countries, only a small amount of laboratory studies have been done, and there are no reports about their application in practical engineering [19-25].

When $\mathrm{MgO}$ concrete damming technology is applied to actual engineering in China, the added $\mathrm{MgO}$ content in normal concrete is generally determined by autoclave test referring to the Chinese National Standard Autoclave Method for Soundness of Portland Cement (GB/T750-1992) (hereinafter referred to as GB/T750-1992) to take mortar whose material composition is closer to the concrete than neat cement paste as the autoclave specimens. Accordingly, this method is named mortar autoclave method $[26,27]$. RCC which is commonly used in dams of modern water conservancy and hydropower engineering contains fly ash up to $55-70 \%$, which is significantly higher than $25-45 \%$ in normal concrete. Then, compared with normal concrete, how to determine the balanced $\mathrm{MgO}$ content in RCC? At present, there are few reports about this problem, and it will be discussed in this paper so that it is helpful to apply $\mathrm{MgO}$ expansion agent to RCC.

\section{Materials and Methods}

2.1. Materials. Cement used in the test was P.O 42.5 ordinary Portland cement, whose $\mathrm{MgO}$ content is $1.81 \%$, water requirement of normal consistency is $25.4 \%$, specific surface area is $325.7 \mathrm{~m}^{2} / \mathrm{kg}$, and soundness is qualified. The quality of cement conforms to the Chinese National Standard Common Portland Cement (GB175-2007). Fly ash, whose fineness 
is $13.6 \%, \mathrm{SO}_{3}$ content is $0.63 \%$, ignition loss is $1.24 \%$, and water demand ratio is $102.8 \%$, meets grade II ash standard stipulated in the Chinese Electric Power Industry Standard Technical Specification of Fly Ash for Use in Hydraulic Concrete (DL/T5055-2007). Sand was made of artificial limestone sand from a reservoir construction site in Guizhou province, and its fineness modulus is 3.04 and particle gradation is good. The sand meets the requirements of Chinese Electric Power Industry Standard Construction Specification for Hydraulic Roller Compacted Concrete (DL/ T5112-2009). The admixture was water reducing agent, whose water reduction rate is $22 \%$, and it conforms to the Chinese Electric Power Industry Standard Technical Code for Chemical Admixtures for Hydraulic Concrete (DL/T51002014). The chemical composition and the physical properties of the $\mathrm{MgO}$ expanding admixture are shown in Tables 1 and 2, which meet the Chinese Electric Power Industry Standard Technical specification of magnesium oxide expansive for use in hydraulic concrete (DL/T5296-2013).

2.2. Test Methods. Tests included the autoclave test and compressive strength test in this paper.

Before the autoclave test is carried out, the autoclave specimens need to be prepared according to the regulations in GB/T750-1992. Water requirement for preparing mortar specimens is converted by the water-binder ratio of $0.5: 1$, cement-sand ratio of $1: 3.74$, and cementitious material (cement + fly ash) of $196 \mathrm{~kg} / \mathrm{m}^{3}$, referring to the mix proportion of the three-grading RCC used in an actual dam project. The proportion of fly ash in the total amount of cementitious material is $60 \%$, and the added $\mathrm{MgO}$ amount is calculated as a percentage of the total amount of cementitious materials. The dimension of all autoclave specimens is the standard size of $25 \mathrm{~mm} \times 25 \mathrm{~mm} \times 280 \mathrm{~mm}$ specified in GB/T750-1992.

The autoclave test was carried out in turn according to the following steps [28]:

(1) The prepared autoclave specimens are kept in a standard curing room with a temperature of $20 \pm 2^{\circ} \mathrm{C}$ and a humidity of not less than $95 \% \mathrm{RH}$ for $48 \mathrm{~h}$ and then removed from molds.

(2) The demoulded specimens are placed into a constant temperature room of $20 \pm 2^{\circ} \mathrm{C}$ for $1-2 \mathrm{~h}$, and then initial length of specimens is measured by the length comparator and marked as $L_{\mathrm{s}}$ (Figure 1 ).

(3) The measured $L_{\mathrm{s}}$ specimens are put into a boiling box and boiled for $3 \mathrm{~h}$. When the water temperature drops to indoor temperature, the specimens are taken out and then put into the constant temperature room of $20 \pm 2^{\circ} \mathrm{C}$ for $12 \pm 3 \mathrm{~h}$. The length of specimens after boiling is measured by the length comparator and marked as $L_{\mathrm{m}}$.

(4) The measured $L_{\mathrm{m}}$ specimens are placed into an autoclave kettle under a pressure of $2.0 \pm 0.05 \mathrm{MPa}$ for $3 \mathrm{~h}$, as specified in GB/T750-1992 (Figure 2). Thereafter, the autoclave kettle is closed, and the steam in the kettle is released after the pressure falls below 0.1 MPa. When the kettle temperature reduces to $20 \pm 2^{\circ} \mathrm{C}$, the specimens are taken out and then placed into the constant temperature room of $20 \pm 2^{\circ} \mathrm{C}$ for $12 \pm 3 \mathrm{~h}$ again (Figure 3 ). The length of autoclaved specimens is measured by the same length comparator and marked as $L_{\mathrm{f}}$.

(5) The autoclave expansion is calculated as follows:

$$
E=\frac{L_{\mathrm{f}}-L_{\mathrm{s}}}{L} \times 100 \%,
$$

where $E$ is the autoclave expansion rate and $L$ is the effective length of the specimen.

According to the provisions of GB/T750-1992, the soundness of the specimen is judged to be qualified when the autoclave expansion rate of a specimen does not exceed $0.5 \%$.

The compressive strength test was carried out in accordance with the Chinese Electric Power Industry Standard Test Code for Hydraulic Concrete (DL/T5150-2001). At first, the autoclaved specimens (size $25 \mathrm{~mm} \times 25 \mathrm{~mm} \times 280 \mathrm{~mm}$ ) are subjected to the bending test and divided into two small specimens with size $25 \mathrm{~mm} \times 25 \mathrm{~mm} \times 140 \mathrm{~mm}$, and then these small specimens are used in compressive strength test. The fixture used in the strength test is shown in Figure 4. Because there are 2 specimens of $25 \mathrm{~mm} \times 25 \mathrm{~mm} \times 280 \mathrm{~mm}$ in each group of autoclave specimens, and there are 4 small specimens of $25 \mathrm{~mm} \times 25 \mathrm{~mm} \times 140 \mathrm{~mm}$ in each group of compressive specimens. The compressive strength value of each group of specimens is the average of the measured values of the 4 small specimens.

\section{Results and Discussion}

3.1. Autoclave Expansion and Compressive Strength. When different amounts of $\mathrm{MgO}$ were added, the autoclave expansion rate of mortar specimens and the compressive strength of autoclaved specimens are listed in Tables 3 and 4, respectively. Meanwhile, the curve of autoclave expansion rate varying with added $\mathrm{MgO}$ content and the curve of compressive strength varying with added $\mathrm{MgO}$ content are drew as shown in Figure 5.

3.2. Analysis of Results. The autoclave test is based on the autoclaving principle. The specimens of cement-based materials containing $\mathrm{MgO}$ are placed in an environment with a high temperature and a high pressure of $2.0 \pm 0.05 \mathrm{MPa}$ (equivalent to a temperature of $215.7 \pm 1.3^{\circ} \mathrm{C}$ ) so as to cause expansion deformations rapidly. The soundness of cement-based materials containing $\mathrm{MgO}$ is determined by measuring the autoclave expansion. In this way, the expansion deformation of cement-based materials containing $\mathrm{MgO}$, which would have taken years to be known in a normal temperature, can be known in a short time. It can be seen from Figure 5 that the autoclave expansion rate of mortar specimens increases with the increase of added $\mathrm{MgO}$ content. When added $\mathrm{MgO}$ content reaches $12 \%$, there is an obvious inflection point on the curve of autoclave 
TABle 1: Chemical composition of magnesium oxide.

\begin{tabular}{cccccc}
\hline $\mathrm{MgO}$ & $\mathrm{SiO}_{2}$ & $\mathrm{CaO}$ & $\mathrm{Fe}_{2} \mathrm{O}_{3}$ & $\mathrm{Al}_{2} \mathrm{O}_{3}$ & $\mathrm{SO}_{3}$ \\
\hline 91.53 & 2.24 & 1.62 & 0.51 & 0.63 & 0.75 \\
\hline
\end{tabular}

TABle 2: Physical properties of magnesium oxide.

\begin{tabular}{lccc}
\hline $\begin{array}{l}\text { Density } \\
\left(\mathrm{g} / \mathrm{cm}^{3}\right)\end{array}$ & Ignition loss (\%) & Fineness (\%) & Activity index (s) \\
\hline 3.18 & 3.15 & 4.08 & 257 \\
\hline
\end{tabular}

Note: fineness refers to the screen residue over an $80 \mu \mathrm{m}$ square hole sieve.

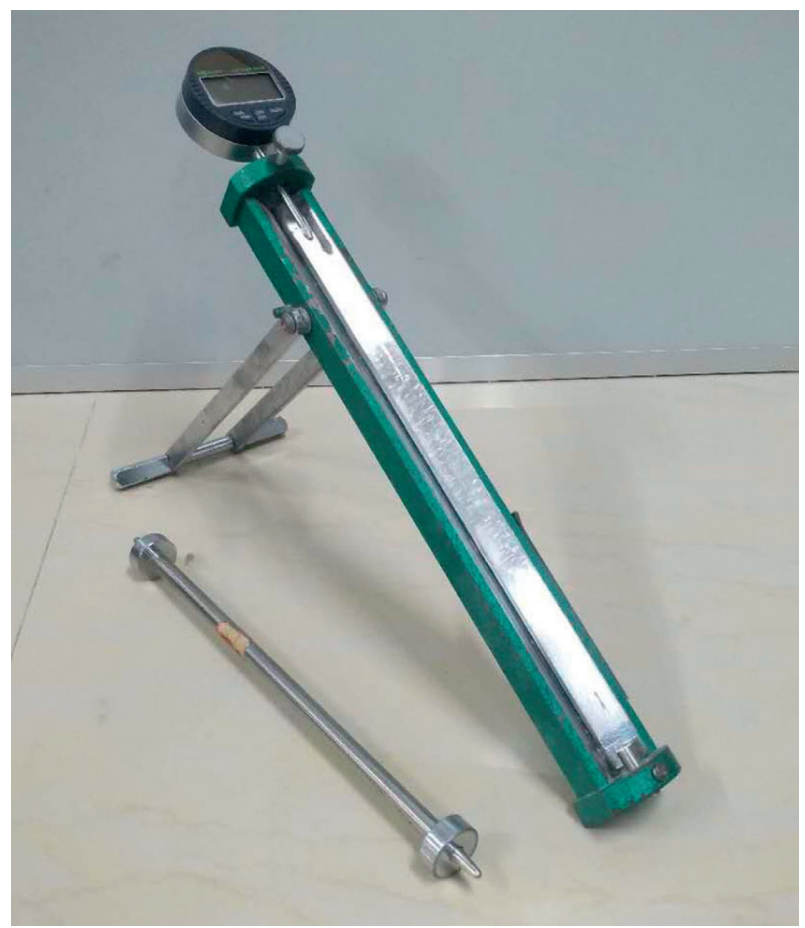

Figure 1: Length comparator.

expansion rate varying with added $\mathrm{MgO}$ content. According to $\mathrm{GB} / \mathrm{T} 750-1992$, the balanced $\mathrm{MgO}$ content is about $13 \%$ when it is determined by the $\mathrm{MgO}$ content corresponding to the autoclave expansion rate of $0.5 \%$ and about $12 \%$ when it is determined by the $\mathrm{MgO}$ content corresponding to the inflection point of the curve of autoclave expansion rate varying with added $\mathrm{MgO}$ content [29].

That is, the balanced $\mathrm{MgO}$ content which is determined by mortar specimens prepared with reference to the mix proportion of RCC is as high as $12-13 \%$. However, according to the existing experimental research results, the balanced $\mathrm{MgO}$ content which is determined by mortar specimens prepared with reference to the mix proportion of normal concrete is generally $3.5-5 \%$ [26]. The former is $7-9.5 \%$ more than the latter, which is closely related to the following two reasons. Firstly, fly ash can obviously restrain the expansion deformation of the mortar mixed with $\mathrm{MgO}[21,30]$. In this test, the fly ash content in mortar specimens accounted for $60 \%$ of the total amount of cementitious material, which is significantly higher than that of the fly ash content of normal concrete (generally 25-45\%). Compared with the specimens

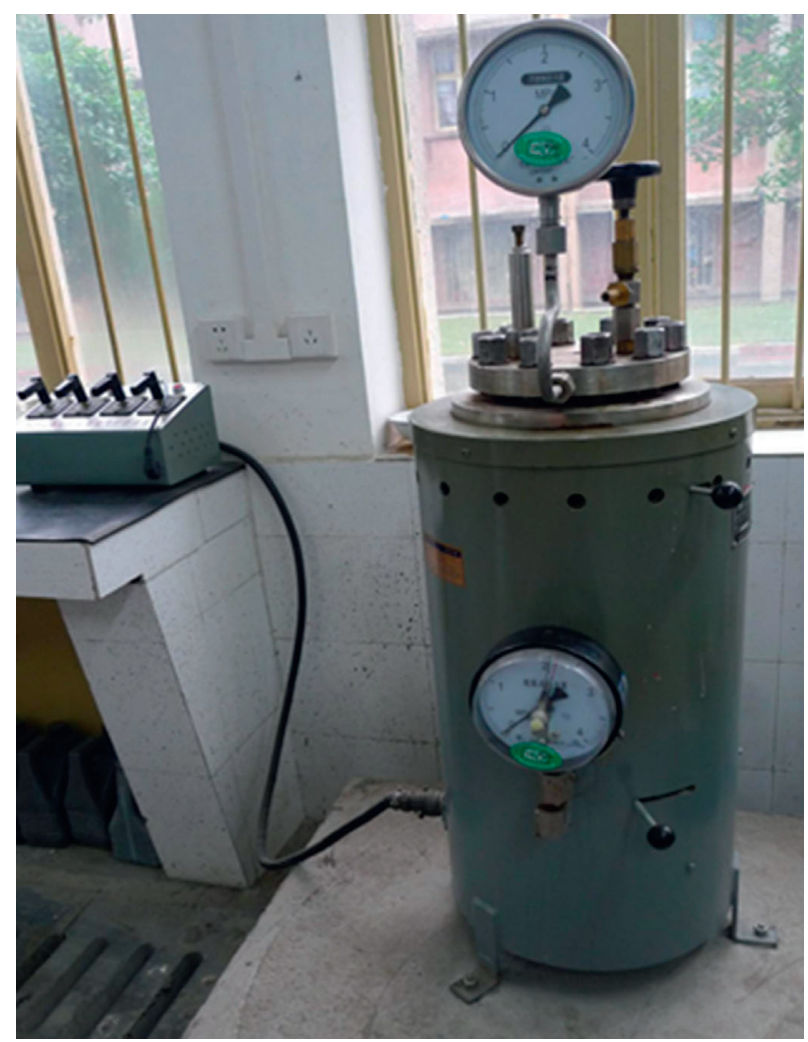

Figure 2: Autoclave kettle.

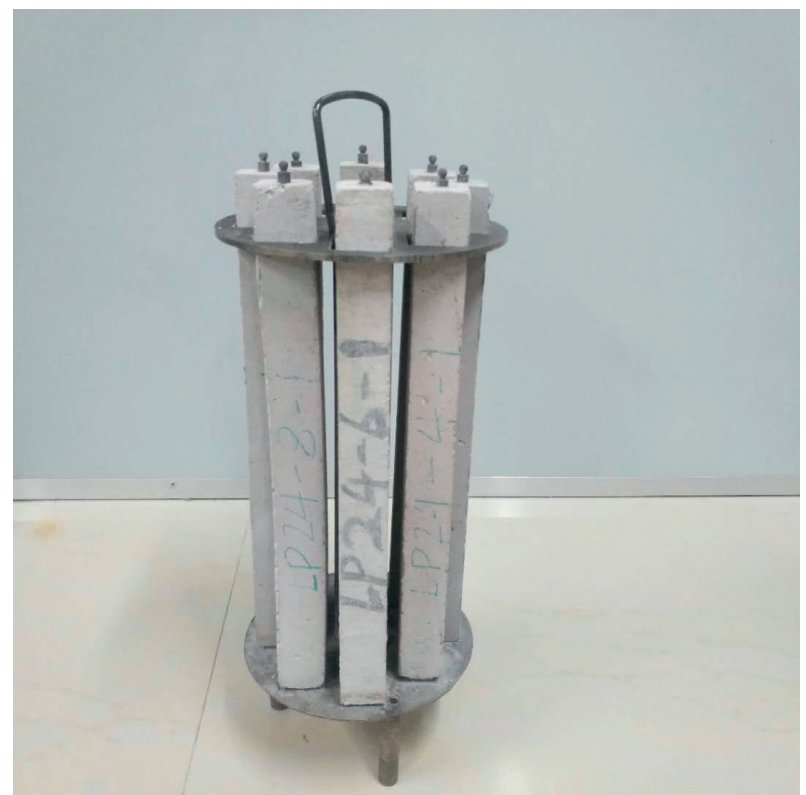

Figure 3: Autoclaved specimens.

with low fly ash content, the significant increase of fly ash content in the specimens leads to a significant reduction in the autoclave expansion rate. Secondly, the amount of cementitious material in RCC is generally about $20 \mathrm{~kg} / \mathrm{m}^{3}$ lower than that of normal concrete. When the percentage of added $\mathrm{MgO}$ is the same, the $\mathrm{MgO}$ content of mortar specimens prepared with reference to the mix proportion of RCC is naturally 


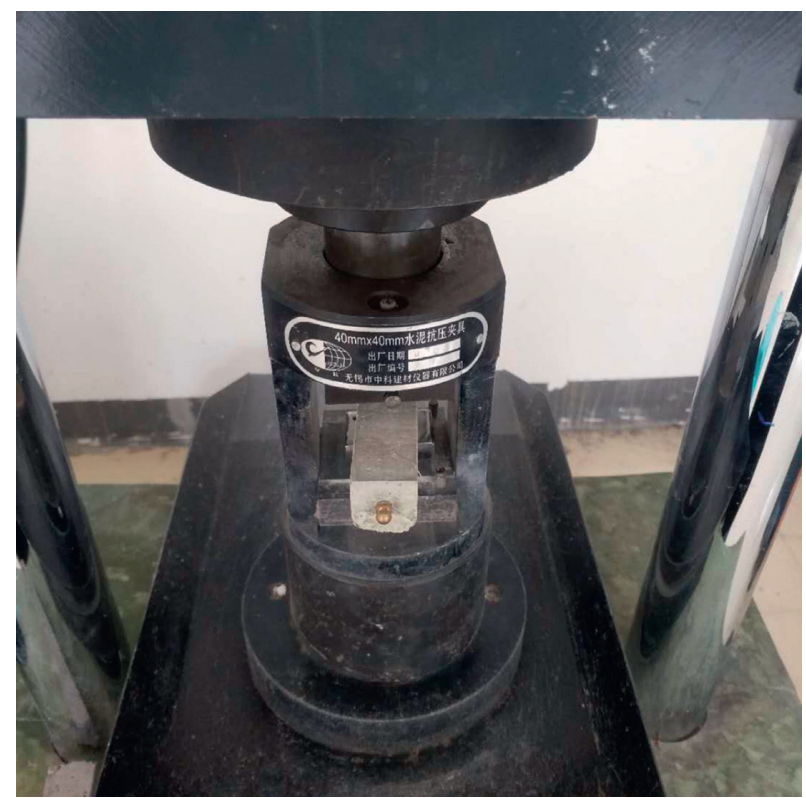

FIGURE 4: Fixture for testing compressive strength.

TABLE 3: Autoclave expansion rate of mortar specimens.

\begin{tabular}{|c|c|c|c|c|}
\hline $\begin{array}{l}\text { Added MgO content (\%) } \\
\text { Autoclave expansion rate (\%) } \\
\text { Judgment of soundness }\end{array}$ & $\begin{array}{c}4 \\
0.0997 \\
\text { Soundness } \\
\end{array}$ & $\begin{array}{c}5 \\
0.1053 \\
\text { Soundness } \\
\end{array}$ & $\begin{array}{c}6 \\
0.1132 \\
\text { Soundness } \\
\end{array}$ & $\begin{array}{c}7 \\
0.1277 \\
\text { Soundness } \\
\end{array}$ \\
\hline $\begin{array}{l}\text { Added MgO content (\%) } \\
\text { Autoclave expansion rate (\%) } \\
\text { Judgment of soundness }\end{array}$ & $\begin{array}{c} \\
0.1368 \\
\text { Soundness } \\
\end{array}$ & $\begin{array}{c}9 \\
0.1483 \\
\text { Soundness } \\
\end{array}$ & $\begin{array}{c}10 \\
0.1617 \\
\text { Soundness } \\
\end{array}$ & $\begin{array}{c}11 \\
0.2112 \\
\text { Soundness } \\
\end{array}$ \\
\hline $\begin{array}{l}\text { Added MgO content (\%) } \\
\text { Autoclave expansion rate (\%) } \\
\text { Judgment of soundness }\end{array}$ & $\begin{array}{c}12 \\
0.2576 \\
\text { Soundness }\end{array}$ & $\begin{array}{c}13 \\
0.5002 \\
\text { Unsoundness }\end{array}$ & $\begin{array}{c}14 \\
0.7945 \\
\text { Unsoundness }\end{array}$ & $\begin{array}{c}15 \\
1.0955 \\
\text { Unsoundness }\end{array}$ \\
\hline
\end{tabular}

TABLE 4: Compressive strength of autoclaved mortar specimens.

\begin{tabular}{|c|c|c|c|c|c|c|c|c|c|c|c|c|}
\hline dd & 4 & 5 & 6 & 7 & 8 & 9 & 10 & 11 & 12 & 13 & 14 & \\
\hline MPa) & 18.75 & 20.88 & 21.58 & 21.33 & 20.97 & 18.43 & 17.35 & 16.30 & 15.36 & 13.78 & 12.13 & 10.83 \\
\hline
\end{tabular}

lower than that of mortar specimens prepared by the mix proportion of normal concrete. The rapid expansion of the autoclave specimens mixed with $\mathrm{MgO}$ originates from the increase of the specimens volume caused by the rapid hydration of $\mathrm{MgO}$ to form $\mathrm{Mg}(\mathrm{OH})_{2}$ crystals in a high temperature and a high pressure. Therefore, the autoclave expansion of the specimen will decrease naturally as long as the content of the $\mathrm{MgO}$ expansion source decreases. In other words, due to the combined action of the above two factors, $\mathrm{RCC}$ requires more $\mathrm{MgO}$ content than normal concrete in order to achieve the same autoclave expansion. Therefore, when the balanced $\mathrm{MgO}$ content in concrete is determined by the autoclave expansion rate of $0.5 \%$ or the inflection point of the curve of autoclave expansion rate varying with added $\mathrm{MgO}$ content, the balanced $\mathrm{MgO}$ content in RCC is much higher than normal concrete.

Meanwhile, the effect of $\mathrm{MgO}$ expansion on the compressive strength of cement-based materials, which would be seen after several years, can also be known in a short time through the autoclave test. As can be seen from Figure 5, the compressive strength of the autoclaved specimens increases gradually at first and then decreases rapidly with the increase of the added $\mathrm{MgO}$ content. There is an obvious inflection point on the curve of compressive strength varying with added $\mathrm{MgO}$ content. The reason is also the volume expansion caused by the rapid hydration of $\mathrm{MgO}$ to form $\mathrm{Mg}(\mathrm{OH})_{2}$ crystals. When the amount of $\mathrm{MgO}$ added to the cement-based materials is proper, the $\mathrm{Mg}(\mathrm{OH})_{2}$ crystals formed by $\mathrm{MgO}$ hydration can reduce the porosity of mortar specimens, enhance their compactness, and improve their compressive strength. However, when the added $\mathrm{MgO}$ is excessive, the compactness and compressive strength of mortar specimens will decrease because the extrusion caused by excess $\mathrm{Mg}(\mathrm{OH})_{2}$ crystals damages the internal structure of mortar specimens. In this test, the corresponding $\mathrm{MgO}$ content at the inflection point of the curve of compressive strength varying with added $\mathrm{MgO}$ content is $8 \%$. That is, compressive strength has begun to decline although the 


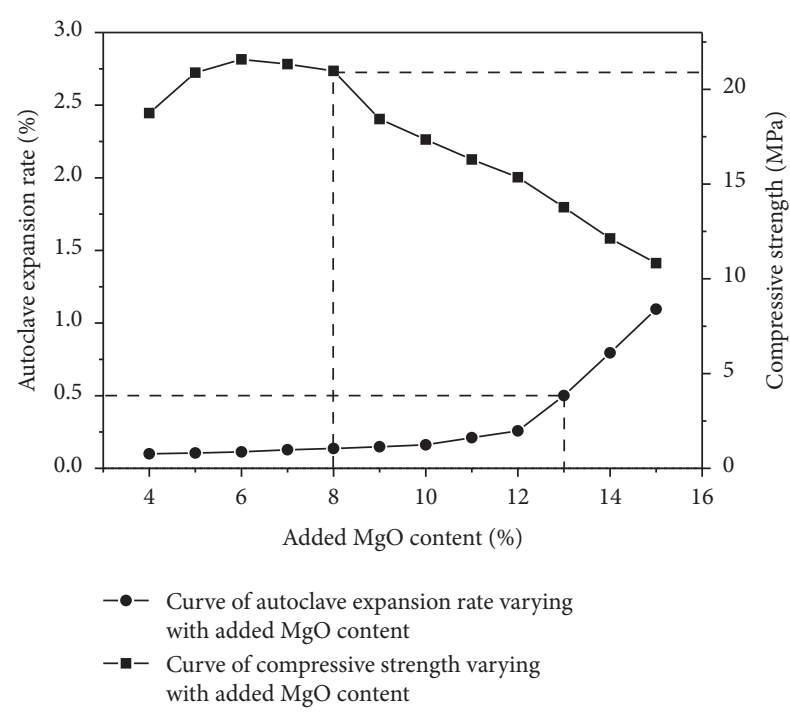

FIgURE 5: Effect of $\mathrm{MgO}$ content in mortar specimens on autoclave expansion rate and compressive strength.

added $\mathrm{MgO}$ content has not reached $12 \%$. This is an undesirable situation for concrete structure because long-term safe operation of buildings is the first priority for all engineers and technicians. Therefore, for the mortar specimens prepared with reference to the mix proportion of RCC, the balanced $\mathrm{MgO}$ content in concrete should be determined by the $\mathrm{MgO}$ content corresponding to the inflection point of the curve of compressive strength varying with added $\mathrm{MgO}$ content but not the autoclave expansion rate of $0.5 \%$ or the inflection point of the curve of autoclave expansion rate varying with added $\mathrm{MgO}$ content.

\section{Conclusions}

In this paper, the autoclave mortar specimens were prepared to test the autoclave expansion and compressive strength by referring to the mix proportion of the threegrading RCC used in a practical water retaining dam and the regulations of GB/T750-1992. The following conclusions can be drawn by analyzing the variation rules of the autoclave expansion rate and the compressive strength of these specimens under different $\mathrm{MgO}$ contents.

(1) The autoclave expansion rate of mortar specimens increases with the increase of $\mathrm{MgO}$ content and increases rapidly when added $\mathrm{MgO}$ content increases to a certain value, which can be seen from the obvious inflection point on the curve of compressive strength varying with added $\mathrm{MgO}$ content. At the same time, the compressive strength of autoclaved mortar specimens increases gradually at first and then decreases rapidly with the increase of added $\mathrm{MgO}$ content, and an obvious inflection point can also be seen on the curve of compressive strength varying with added $\mathrm{MgO}$ content, and the $\mathrm{MgO}$ content corresponding to this inflection point is $4 \%$ lower than that of the curve of autoclave expansion rate varying with added $\mathrm{MgO}$ content.

(2) When the balanced MgO content in the concrete is determined by the autoclave expansion rate of $0.5 \%$ or the inflection point of the curve of autoclave expansion rate varying with added $\mathrm{MgO}$ content, the balanced $\mathrm{MgO}$ content determined by mortar specimen prepared with reference to the mix proportion of RCC is as high as $12-13 \%$, which is $7-9.5 \%$ more than that of mortar specimens prepared with reference to the mix proportion of normal concrete.

(3) The balanced $\mathrm{MgO}$ content in RCC, which cannot be determined by the $\mathrm{MgO}$ content corresponding to autoclave expansion rate of $0.5 \%$ or the inflection point of the curve of autoclave expansion rate varying with added $\mathrm{MgO}$ content like normal concrete, should be determined by the $\mathrm{MgO}$ content corresponding to the inflection point of the curve of compressive strength varying with added $\mathrm{MgO}$ content to ensure the long-term safe operation of RCC dams and that such $\mathrm{MgO}$ amount added in RCC not only is beneficial to give full play to the advantages of $\mathrm{MgO}$ concrete damming technology and promote the application of $\mathrm{MgO}$ expanding admixture in RCC dams but also can ensure the safe operation of RCC dams mixed with MgO.

\section{Data Availability}

The data sets used to support the results of this study are available from the corresponding author upon request.

\section{Conflicts of Interest}

The authors declare that there are no conflicts of interest regarding the publication of this article.

\section{Acknowledgments}

This work was supported by the National Natural Science Foundation of China (grant no. 51869005).

\section{References}

[1] C. M. Li, "An experimental study of the autogenous volume deformation of the $\mathrm{MgO}$ concrete," Journal of Hydroelectric Engineering, vol. 2, pp. 11-20, 1999, in Chinese.

[2] X. Chen, H. Q. Yang, S. H. Zhou, and J. J. Yan, "Crack resistance of concrete with incorporation of light-burnt $\mathrm{MgO}$," Advanced Materials Research, vol. 168-170, pp. 1348-1352, 2010.

[3] C. L. Chen, C. S. Tang, and Z. H. Zhao, "Application of MgO concrete in China Dongfeng arch dam foundation," Advanced Materials Research, vol. 168-170, pp. 1953-1956, 2011.

[4] X. Lu, F. Geng, H. Zhang, and X. Chen, "Influence of MgOtype expansive agent hydration behaviors on expansive properties of concrete," Journal of Wuhan University of Technology-Materials Science Education, vol. 26, no. 2, pp. 344-346, 2011. 
[5] M. D. Yuan, M. Xiao, and G. H. Yang, "Long-term prototype observation data analysis of autogenous deformation of $\mathrm{MgO}$ concrete for Changsha arch dam," Journal of Hydroelectric Engineering, vol. 31, no. 3, pp. 168-174, 2012, in Chinese.

[6] P.-W. Gao, S.-Y. Xu, X. Chen, J. Li, and X.-L. Lu, "Research on autogenous volume deformation of concrete with $\mathrm{MgO}$," Construction and Building Materials, vol. 40, pp. 998-1001, 2013.

[7] Q. X. Zhao, "Review on design of MgO concrete arch dam for 10 years in Guizhou," Water Resources and Hydropower Engineering, vol. 45, no. 2, pp. 53-56, 2014, in Chinese.

[8] Z. H. Zhu, Z. H. Tian, Z. B. Lv et al., "Study on deformation characteristics of micro expansion concrete mixed with $\mathrm{MgO}$ based on the measured data," Science in China (Series E), vol. 44, no. 10, pp. 1027-1034, 2014, in Chinese.

[9] Q. X. Zhao, "Macroscopic deformation of MgO concrete arch dams," Advances in Science and Technology of Water Resources, vol. 35, no. 6, pp. 73-77, 2015, in Chinese.

[10] C. L. Chen, X. P. Shen, and X. M. Chen, "Application of damming technology with $\mathrm{MgO}$ admixed concrete used in the whole dam in Guizhou's arch dam," Advances in Science and Technology of Water Resources, vol. 37, no. 5, pp. 84-88, 2017, in Chinese.

[11] C. M. Li and M. D. Yuan, "Micro-expansion of technology of concrete dam mixed with MgO," Advances in Science and Technology of Water Resources, vol. 23, no. 6, pp. 57-63, 2003, in Chinese.

[12] J. T. Zhang and T. R. Huang, "Design of temperature control of the RCC arch dam for Linhekou hydropower station," Water Power, vol. 30, no. 2, pp. 38-41, 2004, in Chinese.

[13] Z. X. Wu and Z. Zhang, "Design of temperature control for RCC gravity dam of Suofengyin hydropower station," Guizhou Water Power, vol. 19, no. 2, pp. 23-29, 2005, in Chinese.

[14] G. X. Zhang, J. Luo, B. Yang et al., "Simulation and study on thermal stress and temperature control measures for Yujianhe RCC arch dam," Water Resources and Hydropower Engineering, vol. 36, no. 5, pp. 26-29, 2005, in Chinese.

[15] S. Y. Wang, L. L. Qin, and J. W. Deng, "Study on autogenous volume deformation of RCC added with MgO," Journal of Yangtze River Scientific Research Institute, vol. 23, no. 3, pp. 43-46, 2006, in Chinese.

[16] X. M. Xie, "Property study on RCC with MgO addition and temperature simulation in the construction of Madushan dam under high temperatures," J.Xi'an University of Architecture \& Technology (Natural Science Edition), vol. 43, no. 1, pp. 137142, 2011, in Chinese.

[17] Q. X. Zhao, "Key technical problems in construction of Huanghuazhai hydropower station," Water Resources and Hydropower Engineering, vol. 45, no. 1, pp. 90-95, 2014, in Chinese.

[18] H. Su, J. Li, and Z. Wen, "Evaluation of various temperature control schemes for crack prevention in RCC arch dams during construction," Arabian Journal for Science and Engineering, vol. 39, no. 5, pp. 3559-3569, 2014.

[19] P. K. Mehta and D. Pirtz, "Magnesium oxide additive for producing self-stress in mass concrete," Proceedings of the 7th International Congress on the Chemistry of Cement, Paris, France, vol. 12, pp. 6-9, 1980.

[20] S. Chatterji, "Mechanism of expansion of concrete due to the presence of dead-burnt $\mathrm{CaO}$ and $\mathrm{MgO}$," Cement and Concrete Research, vol. 25, no. 1, pp. 51-56, 1995.

[21] M. M. Ali and A. K. Mullick, "Volume stabilisation of high $\mathrm{MgO}$ cement: effect of curing conditions and fly ash addition,"
Cement and Concrete Research, vol. 28, no. 11, pp. 1585-1594, 1998.

[22] L. J. Vandeperre, M. Liska, and A. Al-Tabbaa, "Hydration and mechanical properties of magnesia, pulverized fuel ash, and Portland cement blends," Journal of Materials in Civil Engineering, vol. 20, no. 5, pp. 375-383, 2008.

[23] S.-W. Choi, B.-S. Jang, J.-H. Kim, and K.-M. Lee, "Durability characteristics of fly ash concrete containing lightly-burnt $\mathrm{MgO}$," Construction and Building Materials, vol. 58, no. 5, pp. 77-84, 2014.

[24] V. C. Nguyen, F. G. Tong, and V. N. Nguyen, "Modeling of autogenous volume deformation process of RCC mixed with MgO based on concrete expansion experiment," Construction and Building Materials, vol. 210, pp. 650-659, 2019.

[25] T. Gonçalves, R. V. Silva, J. De Brito, J. M. Fernández, and A. R. Esquinas, "Hydration of reactive $\mathrm{MgO}$ as partial cement replacement and its influence on the macroperformance of cementitious mortars," Advances in Materials Science and Engineering, vol. 2019, pp. 1-12, 2019.

[26] C. L. Chen, "Review on methods for determining soundness admixing amount of magnesium oxide in hydraulic concrete," Water Resources and Hydropower Engineering, vol. 46, no. 9, pp. 135-138, 2015, in Chinese.

[27] J. Z. Li, M. X. Li, and Y. Q. Lin, "Discussion on soundness test method and judgment criteria for magnesium oxide's concrete," Yangtze River, vol. 48, no. 7, pp. 92-95, 2017, in Chinese.

[28] C. Chen, W. Li, D. Yang, Z. Zhao, and H. Yang, "Study on autoclave expansion deformation of $\mathrm{MgO}$-admixed cementbased materials," Emerging Materials Research, vol. 6, no. 2, pp. 422-428, 2017.

[29] DB52/T 720-2010, Technical Specification for MgO-Admixed Concrete Arch Dam Construction, Guizhou Quality and Technical Supervision Bureau, Guizhou, China, 2010, in Chinese.

[30] H. X. Chen and X. W. Ma, "Effects of fly ash on expansion of $\mathrm{MgO}$ expansive cement and its mechanism," Journal of Materials Science and Engineering, vol. 28, no. 2, pp. 182-185, 2010, in Chinese. 